\title{
PERBEDAAN EFEKTIVITAS PEMBERIAN PISANG RAJA DAN PISANG AMBON TERHADAP INDEKS KELELAHAN OTOT ANAEROBIK PADA REMAJA DI SEKOLAH SEPAK BOLA
}

\author{
Vicka Frantya Lone ${ }^{1}$, Martha Ardiaria ${ }^{1}$, Choirun Nissa ${ }^{1}$ \\ ${ }^{1}$ Departemen Ilmu Gizi, Fakultas Kedokteran, Universitas Diponegoro \\ Jln. Prof. H. Soedarto, SH., Semarang, Telp (024) 8453708, Email : gizifk@ undip.ac.id
}

\begin{abstract}
Background : Anaerobic muscle fatigue occurs due to accumulation of lactic acid, causing soreness and reduced muscle contraction. Raja banana (Musa paradisiaca var. Sapientum L.) and Ambon banana (Musa paradisiaca var. Sapientum (L.) Kunt.) are high in carbohydrate and potassium which are involved in increasing blood glucose, thus consuming bananas before exercising may help prevent muscle fatigue.This study aimed to determine the effectiveness of Raja and Ambon bananas on anaerobic. muscle fatigue index of adolescents in football school.

Methods :This study was a quasi-experimentusingthe posttest-only with control group design.Thirty-nine male adolescents aged 15-18 years at Terang Bangsa and Satria Kencana Serasi football schools were recruited and classified into 3 groups: control (240 $\mathrm{ml}$ of mineral water), group I (150 g Raja banana fruit), and group II (150 $\mathrm{g}$ of Ambon banana fruit). Anaerobic muscle fatigue was measured by Running-base Anaerobic Sprint Test (RAST) to calculate Anaerobic Fatigue (AF) value. Data were analyzed by One way ANOVA and ANCOVA test.

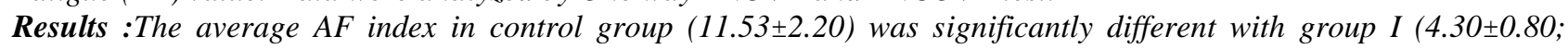
$p=0.001)$, and group I with group II $(9.76 \pm 2.34 ; p=0,001)$. However not significantly different between the averageAF Index of control group withgroup II.

Conclusion :There is a significant difference in the effectiveness of Raja and Ambon banana on reducing anaerobic muscle fatigue for adolescents in football school. Raja banana demonstratedbetter effects on muscle fatiguein comparison withAmbon banana.
\end{abstract}

Keywords: Raja banana, Ambon banana, Anaerobic muscle fatigue, RAST

\begin{abstract}
ABSTRAK
Latar belakang:Kelelahan otot anaerobik terjadi karena akumulasi asam laktat sehingga asam akan menimbulkan nyeri dan menghambat kontraksi otot. Buah pisang raja (Musa paradisiaca var. Sapientum L.) dan pisang ambon (Musa paradisiaca var. Sapientum (L.) Kunt.)mengandung karbohidrat dan tinggi kalium yang akan meningkatkan kadar glukosa darah, sehingga berpotensi dalam mencegah kelelahan otot.

Tujuan penelitian adalah mengetahui perbedaan efektivitas pemberian pisang raja dan pisang ambon terhadap indeks kelelahan otot anaerobik pada remaja disekolah sepak bola.

Metode:Penelitian ini menggunakan desain quasi-experimental dengan rancanganpost test only with control group design. Subjek penelitian adalah39 remaja sepak bola berusia 15-18 tahun di sekolah sepak bola terang bangsa dan satria kencana serasi. Subjek dibagi kedalam 3 kelompok, yaitu kelompok kontrol mendapat air mineral 240 ml, kelompok perlakuan Imendapat pisang raja $150 \mathrm{~g}$ dan kelompok perlakuan II yang mendapat pisang ambon $150 \mathrm{~g}$. Kelelahan otot anaerobik diukur menggunakan RAST (Running-based Anaerobic Sprint Test) dengan menghitung nilai AF (Anaerobic Fatigue). Data dianalisis dengan menggunakan uji One way ANOVA dan uji ANCOVA.

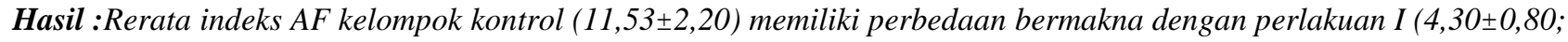
$p=0,001)$ begitu juga perlakuan I dengan perlakuan II (9.76 $\pm 2.34 ; p=0,001)$ namun tidak memiliki perbedaan bermakna pada kelompok kontrol dengan perlakuan II ( $p=0,171)$.

Kesimpulan:Terdapat perbedaan efektivitas antara buah pisang raja dan pisang ambon dalam mengatasi kelelahan otot anaerobik pada remaja di Sekolah Sepak Bola. Pisang raja memiliki efek lebih besar dalam mengatasi kelelahan otot dibanding dengan pisang ambon.
\end{abstract}

Kata kunci: pisang raja, pisang ambon, kelelahan otot anaerobic, RAST

\section{PENDAHULUAN}

Olahraga merupakan aktivitas fisik yang dapat membantu mengoptimalkan perkembangan tubuh melalui gerakan yang disadari dengan otot. Berbagai macam olahraga melibatkan proses aerobik dan anaerobik tergantung pada jenis olahraga. Salah satu cabang olahraga yang memiliki kombinasi proses aerobik dan anaerobik adalah sepakbola. ${ }^{1}$ Sepak bola merupakan olahraga yang membutuhkan power yang tinggi karena dalam olahraga ini terdapat 150-250 gerakan seperti menangkap, menggiring, melompat, mengoper, menendang dan berlari dengan cepat. $^{2}$ Gerakan-gerakan tersebut bersifat anaerobik sehingga dapat menyebabkan kelelahan anaerobik. ${ }^{3}$ Salah satu pengukuran kelelahan otot anaerobik yang dianggap valid yaitu menggunakan tes Runningbased Anaerobic Sprint Test (RAST) ${ }^{4,5}$. 
Aktivitas anaerobik mengutamakan kekuatan otot dengan tenaga ledakan tinggi dan berlangsung dalam waktu singkat. Proses metabolisme anaerobik dapat berjalan tanpa kehadiran oksigen dan akan menghasilkan produk samping berupa asam laktat. Apabila asam laktat terakumulasi dapat menimbulkan nyeri pada otot dan menghambat kontraksi otot. ${ }^{1}$ Kelelahan otot pada intensitas tinggi disebabkan oleh beberapa faktor yaitu tingkat keasaman meningkat karena banyaknya produksi asam laktat; glukosa darah, glikogen hati dan glikogen otot yang tidak memadai serta kurang tepatnya pengaturan makan dan minum pada atlet baik sebelum maupun saat pertandingan berlangsung. ${ }^{6}$

Kelelahan otot anaerobik dapat dikurangi dengan mengonsumsi buah pisang, Buah pisang mengandung karbohidrat sebagai sumber energi sekaligus memiliki kandungan kalium yang tinggi serta mengandung antioksidan. Kandungan buah pisang tersebut dapat memberikan dukungan gizi yang baik selama latihan intensif. ${ }^{7}$ Sebuah studi menyatakan bahwa peningkatan aktivitas $\mathrm{Na}^{+}, \mathrm{K}^{+}$, dan ATPase dapat mencegah terjadinya kelelahan pada saat berolahraga. ${ }^{8}$ Kalium berfungsi dalam hal kekuatan dan kecepatan kontraksi otot. ${ }^{1}$ Berdasarkan penelitian, pemberian 30-60 g/jam karbohidrat dapat mempertahankan level glukosa darah dan menjaga tingkat pembakaran karbohidrat di dalam tubuh sehingga kelelahan dapat dihambat selama 30-60 menit. Karbohidrat merupakan sumber energi utama yang penting untuk latihan dengan intensitas tinggi seperti sepakbola karena olahraga ini dapat berulangkali menggunakan glikogen otot yang tersimpan untuk kinerja yang optimal. ${ }^{6}$

Kandungan karbohidrat pada $100 \mathrm{~g}$ pisang raja yaitu 31,15 g. ${ }^{11}$ Berdasarkan uji pendahuluan laboratorium $100 \mathrm{~g}$ pisang ambon pisang mengandung 24,7 g karbohidrat, sehingga dosis yang diambil dalam penelitian ini yaitu $150 \mathrm{~g}$ pada masingmasing pisang. Selain itu, dosis ini juga mengacu pada penelitian sebelumnya bahwa pisang 150 gram dapat mengatasi kelelahan otot anaerobik pada atlet sepak takraw. ${ }^{12}$

Pada studi sebelumnya mengenai perbedaan efektivitas pemberian pisang raja dan pisang ambon terhadap kelelahan otot pada tikus galur wistar menunjukkan bahwa pisang raja merupakan hasil terbaik dalam mencegah kelelahan. ${ }^{13}$ Penelitian menggunakan pisang ambon dan pisang raja yang dihubungkan dengan kelelahan otot anaerobik pada saat ini sebatas uji laboratorium saja dengan sampel tikus dan belum di intervensikan pada subjek manusia. Penelitian yang dilakukan pada subjek manusia hanya meneliti satu sampel pisang dan tidak membandingkan antara pisang raja dan pisang ambon. Pisang raja dan ambon termasuk pangan lokal unggulan di Jawa Tengah yang mudah didapat dimana saja dan lebih terjangkau. Berdasarkan uraian diatas, maka peneliti ingin melakukan penelitian mengenai perbedaan efektivitas pemberian pisang raja dan pisang ambon terhadap indeks kelelahan otot anaerobik pada remaja di Sekolah Sepak Bola.

\section{METODE}

Penelitian ini merupakan penelitian Quasi Experimental dengan rancangan post test only with control group design. Variabel terikat (dependent) dalam penelitian ini adalah nilai indeks kelelahan otot anaerobik/Anaerobic Fatigue (AF). Variabel bebas (independent) dalam penelitian ini adalah pemberian buah pisang raja (Musa paradisiaca var. Sapientum L.) dan pisang ambon (Musa paradisiaca var. Sapientum (L.) Kunt.) masing-masing dengan dosis 150 g. Variabel perancu adalah energi, karbohidrat, kalium, kalsium, dan natrium. Perhitungan subjek penelitian menggunakan rumus analitik numerik tidak berpasangan sehingga dibutuhkan minimal 39 subjek yang dibagi menjadi 3 kelompok yaitu 13 remaja kelompok kontrol (air mineral $240 \mathrm{ml}$ ), 13 remaja kelompok perlakuan I (pisang raja $150 \mathrm{~g}$ ), dan 13 remaja kelompok perlakuan II (pisang ambon 150 g).

Subjek penelitian ditentukan dengan menggunakan teknik consecutive sampling yaitu mengambil semua subjek yang datang dan memenuhi kriteria inklusi sebagai berikut: subjek merupakan remaja sepak bola laki-laki 15-18 tahun yang berada di Asrama Sekolah Sepak Bola Terang Bangsa Kota Semarang dan Satria Kencana Serasi Kabupaten Semarang; tidak melakukan aktivitas fisik yang melelahkan, tidak mengonsumsi suplemen, obat herbal, kafein, minuman berelektrolit, sport drink, dan minuman berenergi yang berfungsi sebagai pembangkit tenaga selama 24 jam sebelum intervensi;tidak dalam perawatan dokter atau pascaoperasi 6 bulan sebelum penelitian; tidak sedang mengalami cidera; bersedia mengikuti penelitian melalui persetujuan Informed consent. Subjek dinyatakan keluar dari penelitian apabila sakit atau mengalami cidera selama penelitian berlangsung; menyatakan keluar dari penelitian.

Pisang raja dan pisang ambon dalam penelitian ini diberikan dalam bentuk buah utuh untuk menghindari browning yang akan menurunkan nilai gizinya dan mengurangi kualitas visual sehingga akan mempengaruhi nilai organoleptik bagi yang mengonsumsinya. ${ }^{12}$ Pengujian nilai gizi pisang ambon $100 \mathrm{~g}$ diuji di Laboratorium Ilmu Pangan Universitas Soegijapranata Semarang.

Indeks Anaerobic Fatigue (AF) dihitung menggunakan test RAST (Running-based Anaerobic Sprint Test). RAST dilakukan setelah 3 jam makan 
utama dengan jenis makanan dan porsi yang sama. Pada penelitian ini pemberian pisang raja dan pisang ambon setelah dua jam makan, kemudian 30 menit sebelum dilakukan test RAST remaja diberikan air mineral $240 \mathrm{ml}$ pada kelompok perlakuan I, perlakuan II, dan kontrol. Uji RAST dilaksanakan siang hari pukul $11.00 \mathrm{WIB}$. Prosedur pelaksanaan uji RAST adalah subjek diminta melakukan pemanasan selama 10 menit. Selanjutnya subjek diminta berlari sprint sebanyak 6 kali repetisi sejauh 35 meter dengan kecepatan maksimum dengan fase istirahat 10 detik setiap repetisi, didapatkan power maksimum berupa nilai tertinggi diantara 6 kali repetisi. Data tersebut dihitung dengan rumus baku AF (Anaerobic Fatigue) dan subjek diistirahatkan.

Pencatatan asupan makan 24 jam sebelum uji RAST dilakukan dengan metode food recall 24 jam dan pencatatan kebiasaan makan dilakukan dengan metode Semi-Quantitative Food Frequency Questionnaire (SFFQ) data asupan dianalisis menggunakan program nutrisurvey. Nilai indeks Anaerobic Fatigue (AF) pada remaja didapatkan dari hasil uji RAST dengan rumus $\mathrm{AF}=$ (Power maksimum - Powerminimum) / total waktu 6 kali sprint. Subjek dikatakan mengalami kelelahan apabila nilai AF $>10 .{ }^{4,5}$ Data nilai Anaerobic Fatigue
(AF) antara kelompok kontrol, perlakuan I, dan perlakuan II diuji normalitas datanya menggunakan uji Saphiro Wilk karena sampel kurang dari 50. Perbedaan rerata nilai Anaerobic Fatigue (AF) antara kelompok perlakuan I, perlakuan II, dan kontrol menggunakan One way ANOVA dan perbedaan dianggap bermakna apabila $\boldsymbol{p}<0,05$. Pengujian variabel perancu menggunakan ANCOVA dianggap bermakna apabila $\boldsymbol{p}<0,05$.

\section{HASIL PENELITIAN}

Hasil skrining awal yang diikuti oleh 50remaja di Sekolah Sepakbola Terang Bangsa Kota Semarang dan Satria Kencana Serasi Kabupaten Semarang menunjukkan sebanyak 45 remaja (90\%) yang memenuhi kriteria inklusi.

\section{Karakteristik Subjek Penelitian}

Terdapat 5 subjek cidera dan 1 subjek mengundurkan diri dari penelitian sehingga subjek yang mengikuti sampai akhir penelitian sebanyak 39 subjek. Tabel karakteristik menunjukkan sebaran usia dan status gizi berdasarkan Indeks Massa Tubuh per Usia (IMT/U) pada kelompok kontrol, perlakuan I, dan perlakuan II. Gambaran karakteristik subjek terdapat dalam Tabel 1 berikut:

Tabel 1. Karakteristik subjek penelitian $(n=39)$

\begin{tabular}{|c|c|c|c|c|c|c|c|c|c|c|}
\hline & \multicolumn{3}{|c|}{ Kontrol } & \multicolumn{3}{|c|}{ Perlakuan I } & \multicolumn{3}{|c|}{ Perlakuan II } & \multirow{2}{*}{$p$} \\
\hline & Min & Max & Rerata \pm SD & Min & Max & Rerata \pm SD & Min & Max & Rerata $\pm S D$ & \\
\hline Usia & 15 & 17 & $15,62 \pm 0,87$ & 15 & 17 & $15,92 \pm 0,7$ & 15 & 17 & $15,77 \pm 0,83$ & $0,539^{\mathrm{a}}$ \\
\hline $\begin{array}{l}\text { Berat } \\
\text { badan }\end{array}$ & 41,0 & 62,6 & $54,7 \pm 6,4$ & 43,0 & 69,7 & $56,5 \pm 8,5$ & 47,9 & 71,5 & $56,4 \pm 6,3$ & $0,776^{\mathrm{b}}$ \\
\hline $\begin{array}{l}\text { Tinggi } \\
\text { badan }\end{array}$ & 152,2 & 174,6 & $163,6 \pm 5,9$ & 155,5 & 178 & $166,1 \pm 6,1$ & 158,3 & $\begin{array}{r}175 \\
1\end{array}$ & $164,2 \pm 4,5$ & $0,522^{b}$ \\
\hline IMT/U & $-1,14$ & 0,67 & $-0,08 \pm 0,58$ & $-2,67$ & 1,23 & $-0,20 \pm 0,99$ & $-0,97$ & 1,33 & $0,07 \pm 0,72$ & $0,662^{\mathrm{b}}$ \\
\hline
\end{tabular}

Tabel 1 menunjukkan rerata usia subjek berkisar 15-18 tahun. Menurut Depkes (2005) masa remaja dibedakan dalam tiga tahap yaitu remaja awal (10-13 tahun), remaja tengah (14-16 tahun) dan remaja akhir (17-19 tahun). Rerata nilai dari IMT/U termasuk dalam kategori normal (z-score $-2 \mathrm{~s} / \mathrm{d}+2)$ yang mengacu pada referensi WHO 2007. Status gizi digunakan untuk mengetahui apakah seseorang atau sekelompok orang tersebut memiliki status gizi baik atau tidak.

Berdasarkan uji one way ANOVA dan Kruskal-wallis menunjukkan $\boldsymbol{p}>0,05$ sehingga dapat disimpulkan bahwa tidak terdapat perbedaan usia, berat badan, tinggi badan, dan IMT/U antar kelompok.

Asupan Makan Subjek selama 24 Jam Sebelum Intervensi

Remaja diberikan tiga kali makan utama dalam sehari. Makanan tersebut disajikan menggunakan kardus makanan dan sudah diporsikan dengan jenis dan jumlah yang sama. Data recall 24 jam terhitung dari setelah makan pagi hingga esok pagi pada saat pelaksanaan pengambilan data. Asupan zat gizi subjek kelompok kontrol, perlakuan I, dan perlakuan II sebelum intervensi disajikan dalam Tabel 2. 
Tabel 2. Asupan zat gizi sebelum intervensi

\begin{tabular}{|c|c|c|c|c|c|c|}
\hline & $\begin{array}{l}\text { Asupan } \\
\text { Energi } \\
\text { (kkal) }\end{array}$ & $\begin{array}{l}\text { Asupan } \\
\text { Karbohidrat } \\
\text { (g) }\end{array}$ & $\begin{array}{l}\text { Asupan } \\
\text { Kalium } \\
(\mathrm{mg})\end{array}$ & $\begin{array}{l}\text { Asupan } \\
\text { Kalsium } \\
\text { (mg) } \\
\end{array}$ & $\begin{array}{l}\text { Asupan } \\
\text { Magnesium } \\
\text { (mg) }\end{array}$ & $\begin{array}{l}\text { Asupan } \\
\text { Natrium } \\
\text { (mg) } \\
\end{array}$ \\
\hline \multicolumn{7}{|c|}{ Kontrol $(n=13)$} \\
\hline Minimum & 1765,20 & 196,50 & 965,00 & 120,40 & 177,6 & 1214,50 \\
\hline Maksimum & 3524,70 & 497,10 & 4153,40 & 1483,00 & 500,2 & 1839,6 \\
\hline Rerata \pm SD & $2781,8 \pm 483,3$ & $368,10 \pm 84,5$ & $1871,90 \pm 883$ & $572,2 \pm 480,9$ & $278,9 \pm 78,4$ & $1639 \pm 153,8$ \\
\hline \multicolumn{7}{|c|}{ Perlakuan $\mathrm{I}(\mathrm{n}=13)$} \\
\hline Minimum & 2284,80 & 268,50 & 947,90 & 167,50 & 178 & 1245,20 \\
\hline Maksimum & 3764 & 454,30 & 4727,30 & 931,00 & 563,3 & 1896,90 \\
\hline Rerata \pm SD & $2752,2 \pm 418,8$ & $363,68 \pm 53,8$ & $1937,40 \pm 1015$ & $647,9 \pm 280,1$ & $293,7 \pm 110$ & $1504 \pm 188,1$ \\
\hline \multicolumn{7}{|c|}{ Lanjutan Tabel 2. Asupan zat gizi sebelum intervensi } \\
\hline \multicolumn{7}{|c|}{ Perlakuan II (n=13) } \\
\hline Minimum & 2152,60 & 276,30 & 1132,40 & 152,60 & 181,1 & 1164,90 \\
\hline Maksimum & 3124,50 & 449,40 & 4580,10 & 1539,30 & 487,9 & 1662,10 \\
\hline Rerata \pm SD & $2596,7 \pm 285,1$ & $349,06 \pm 53,6$ & $1795,00 \pm 918,3$ & $503,9 \pm 394,2$ & $256 \pm 74,6$ & $1405,5 \pm 144,4$ \\
\hline
\end{tabular}

Berdasarkan Tabel 2 menunjukkan bahwa rerata asupan energi, karbohidrat, dan natrium pada kelompok kontrol lebih tinggi daripada kelompok lainnya. Rerata asupan kalium, kalsium, dan magnesium pada kelompok perlakuan I lebih tinggi daripada kelompok kontrol maupun perlakuan II.
Setelah diketahui asupan zat gizi sebelum intervensi, berikut adalah kecukupan zat gizi pada remaja yang dihitung menggunakan rumus Harris Benedict yang dikategorikan dalam tiga kategori berikut ini:

Tabel 3. Kategori kecukupan zat gizi sebelum intervensi

\begin{tabular}{|c|c|c|c|c|c|c|c|c|c|c|c|c|}
\hline \multirow{3}{*}{ Kelompok } & \multicolumn{6}{|c|}{ Kecukupan Energi } & \multicolumn{6}{|c|}{ Kecukupan Karbohidrat } \\
\hline & \multicolumn{2}{|c|}{ Kurang } & \multicolumn{2}{|c|}{ Cukup } & \multicolumn{2}{|c|}{ Lebih } & \multicolumn{2}{|c|}{ Kurang } & \multicolumn{2}{|c|}{ Cukup } & \multicolumn{2}{|c|}{ Lebih } \\
\hline & $\mathbf{n}$ & $\begin{array}{l}\text { Persen } \\
(\%)\end{array}$ & $\mathbf{n}$ & $\begin{array}{l}\text { Persen } \\
(\%)\end{array}$ & $\mathbf{n}$ & $\begin{array}{l}\text { Persen } \\
(\%)\end{array}$ & $\mathbf{n}$ & $\begin{array}{l}\text { Persen } \\
(\%)\end{array}$ & $\mathbf{n}$ & $\begin{array}{l}\text { Persen } \\
(\%)\end{array}$ & $\mathbf{n}$ & $\begin{array}{l}\text { Persen } \\
(\%)\end{array}$ \\
\hline Kontrol & 6 & 46,1 & 5 & 38,4 & 2 & 15,3 & 7 & 53,8 & 6 & 46,1 & 0 & 0 \\
\hline Perlakuan I & 8 & 61,5 & 4 & 30,7 & 1 & 7,6 & 11 & 84,6 & 2 & 15,3 & 0 & 0 \\
\hline Perlakuan II & 9 & 69,2 & 4 & 30,7 & 0 & 0 & 10 & 76,9 & 3 & 23,07 & 0 & 0 \\
\hline
\end{tabular}

Tabel 3 merupakan data pengelompokan tingkat kecukupan asupan energi dan karbohidrat remaja sebelum intervensi. Berdasarkan Widyakarya Nasional Pangan dan Gizi (WNPG) 2012 yaitu asupan $\geq 120 \%$ dikategorikan berlebih, $90-119 \%$ cukup, dan $<90 \%$ kurang.Hasil data pada tabel tersebut menunjukkan bahwa rata-rata kecukupan energi dan karbohidrat antara ketiga kelompok yaitu tergolong kurang.
Perbedaan Efektivitas Pemberian Antar Kelompok terhadap Nilai Indeks Kelelahan Otot Anaerobik / Anaerobic Fatigue (AF) setelah Intervensi

Nilai Indeks AF diperoleh dari tes RAST yaitu selisih antara power maksimal dan power minimal dibagi dengan total waktu. Dikatakan masuk kategori lelah bila AF $>10$ dan dikatakan tidak lelah bila $\mathrm{AF}<10$. Berikut kategori dan perbedaan indeks $\mathrm{AF}$ :

Tabel 4.Kategori dan perbedaan IndeksAnaerobic Fatigue (AF)

\begin{tabular}{|c|c|c|c|c|c|c|}
\hline \multirow[t]{3}{*}{ Kelompok } & \multicolumn{4}{|c|}{ IndeksAnaerobic Fatigue (AF) } & \multirow[t]{3}{*}{ Rerata \pm SD } & \multirow[t]{3}{*}{ Nilai $p^{b}$} \\
\hline & \multicolumn{2}{|c|}{$>10$ (lelah) } & \multicolumn{2}{|c|}{$<10$ (tidak lelah) } & & \\
\hline & Frekuensi & $\begin{array}{r}\text { Persen } \\
(\%)\end{array}$ & Frekuensi & $\begin{array}{r}\text { Persen } \\
(\%)\end{array}$ & & \\
\hline Kontrol & 10 & 76,92 & 3 & 23,07 & $11,53 \pm 2,20$ & 0,001 \\
\hline Perlakuan I & 0 & 0 & 13 & 100 & $4,30 \pm 0,80$ & \\
\hline Perlakuan II & 7 & 53,84 & 6 & 46,15 & $9,76 \pm 2,34$ & \\
\hline
\end{tabular}

${ }^{\mathrm{b}} \mathrm{Uji}$ One way ANOVA. Analisis post hoc Tamhane: Pisang raja vs pisang ambon $\boldsymbol{p}<0,001$; Kontrol vs pisang raja $\boldsymbol{p}<0,001$; Kontrol vs pisang ambon $p=0,171$ 
Berdasarkan kategori AF pada tabel 4 dapat dilihat bahwa 76,92\% kelompok kontrol dan diikuti oleh perlakuan II sebanyak 53,84\% subjek tergolong lelah. Hanya kelompok perlakuan I yang keseluruhan subjek tidak lelah.

Berdasarkan uji statistik pada Tabel 4 dapat disimpulkan bahwa tidak terdapat perbedaan indeks Anaerobic Fatigue (AF) antara kelompok kontrol dengan pisang ambon $(\boldsymbol{p}>0,05)$. Namun terdapat perbedaan Anaerobic Fatigue (AF) antara kelompok pisang raja dengan pisang ambon dan kontrol dengan pisang raja $(\boldsymbol{p}<0,05)$.

Pengaruh Variabel Perancu terhadap Indeks Kelelahan Otot Anaerobik/Anaerobik Fatigue (AF)

Tabel 5. Pengaruh Variabel Perancu terhadap Indeks AF

\begin{tabular}{lc}
\hline \multicolumn{1}{c}{ Variabel } & $\boldsymbol{p}^{\mathbf{c}}$ Indeks AF \\
\hline Kecukupan Energi & 0,256 \\
Kecukupan Karbohidrat & 0,516 \\
Asupan Kalium & 0,202 \\
Asupan Kalsium & 0,360 \\
Asupan Natrium & 0,624 \\
\hline
\end{tabular}

${ }^{\mathrm{c} U j i}$ ANCOVA

Tabel 5. Menunjukkan bahwa $(\boldsymbol{p}>0,05)$ tidak terdapat pengaruh asupan energi, karbohidrat, kalium, kalsium, dan natrium subjek terhadap indeks AF.

\section{PEMBAHASAN}

Kelelahan otot anaerobik pada remaja sepakbola dapat dikurangi dengan pemberian buah pisang. Hasil uji one way ANOVA menunjukkan bahwa tidak terdapat perbedaan indeks AF pada kelompok kontrol (240 $\mathrm{ml}$ air mineral) dengan perlakuan II (pisang ambon) ditunjukkan dengan nilai $\boldsymbol{p}>0,05$. Kelompok kontrol dengan perlakuan I (pisang raja) dan kelompok perlakuan I dengan perlakuan II menunjukkan adanya perbedaan yang bermakna ditunjukkan dengan nilai $\boldsymbol{p}<0,05$, namun jika dilihat dari rerata dan frekuensi indeks $\mathrm{AF}$ menunjukkan bahwa perlakuan I lebih efektif daripada perlakuan II. Hal ini dapat disimpulkan bahwa terdapat perbedaan efektivitas pemberian pisang raja dan pisang ambon dalam mengatasi kelelahan otot anaerobik dan penelitian ini membuktikan hipotesis yang ada. Semakin rendah nilai $\mathrm{AF}(<10)$ maka dapat dikatakan bahwa remaja tidak mengalami kelelahan. Sedangkan apabila nilai $\mathrm{AF}(>10)$ maka dapat dikatakan remaja mengalami kelelahan. Running-based Anaerobic Sprint Test (RAST) adalah salah satu tes yang cocok digunakan oleh olahraga sepak bola dalam mengukur kelelahan otot anaerobik dengan melihat indeks AF. ${ }^{4,5}$

Penelitian 150 dan $300 \mathrm{~g}$ pisang raja terbukti dapat mencegah kelelahan otot anaerobik pada atlet sepak takraw. ${ }^{10}$ Peningkatan kadar glukosa darah setelah konsumsi $150 \mathrm{~g}$ dan $300 \mathrm{~g}$ pisang berpotensi dalam mencegah kram otot. Kelelahan otot yang terjadi secara terus-menerus akan mengakibatkan kram otot. ${ }^{13}$ Peningkatan aktivitas $\mathrm{Na}^{+}, \mathrm{K}^{+}$, dan ATPase selama olahraga akan menstabilkan natrium dan kalium sehingga dapat mencegah kelelahan. ${ }^{14}$ Penelitian lain yang membandingkan efek dari pemberian pisang dengan minuman berkarbohidrat 6\% pada remaja sepeda $75 \mathrm{~km}$, menunjukkan bahwa tidak ada perbedaan antara kadar glukosa darah dan performa pada kelompok yang diberikan pisang $(2,41 \pm 0,1)$ dengan kelompok yang diberi minuman berkarbohidrat $6 \% \quad(2,36 \pm 0,19)$, namun pada kelompok yang diberikan pisang memiliki kadar antioksidan dopamin yang lebih tinggi daripada kelompok yang diberi minuman berkarbohidrat $6 \% .{ }^{15}$ Konsumsi karbohidrat 45-75 g sebelum olahraga akan meningkatkan jumlah simpanan glikogen 25$100 \%$ sehingga dapat menunda kelelahan hingga 20\% saat melakukan olahraga. ${ }^{16}$ Pemberian karbohidrat sebesar 30-60 g/jam dapat mempertahankan level glukosa darah dan dapat menghambat kelelahan otot hingga 30-60 menit. ${ }^{17}$

Berdasarkan penelitian dan uji pendahuluan laboratorium kandungan zat gizi pada $150 \mathrm{~g}$ pisang raja dan ambon berturut-turut adalah adalah 46,7 dan 37,05 g karbohidrat; 1,18 dan 1,53 g protein; 0,27 dan $0 \mathrm{~g}$ lemak; 697,5 dan $325,5 \mathrm{mg}$ kalium. ${ }^{9}$ Zat gizi yang berperan langsung dalam memperlambat kelelahan otot pada penelitian ini adalah karbohidrat dan kalium.

Karbohidrat merupakan sumber energi utama yang penting untuk latihan dengan intensitas tinggi seperti sepakbola karena olahraga ini dapat berulangkali menggunakan glikogen otot yang tersimpan untuk kinerja yang optimal. ${ }^{6}$ Karbohidrat dapat meningkatkan kadar glukosa darah, dan dapat menjadi glikogen hati maupun glikogen otot. Konsumsi karbohidrat 2-3 jam setelahnya akan meningkatkan kadar glukosa darah sehingga dapat digunakan sebagai sumber energi. Nilai tertinggi glukosa pada dua jam pertama setelah makan. ${ }^{18,19}$ Karbohidrat dalam buah pisang berupa karbohidrat sederhana yaitu glukosa, fruktosa, dan sukrosa sebagai energi yang mudah tersedia dalam waktu singkat sehingga sesuai untuk metabolisme anaerob. 15

Aktivitas secara terus menerus dengan intensitas tinggi pada olahraga sepak bola bersifat anaerob sehingga akan mengurangi cadangan sumber energi dan terakumulasinya asam laktat dalam otot. Hal tersebut akan menyebabkan menurunnya kontraksi otot dan kelelahan otot. Proses metabolisme pada fase anaerob terdiri dari dua sistem yaitu ATP$\mathrm{PCr}$ (Phosphocreatine) yang dikenal sebagai sistem 
fosfat dan glikolisis yang biasa disebut sistem asam laktat. ${ }^{6}$ Meskipun PCr tidak dapat digunakan secara langsung sebagai sumber energi, tapi dapat dengan cepat mengisi ATP (adenosine triphosphate). Phosphocreatine dan ATP ditemukan didalam tubuh dalam jumlah yang kecil dan hanya dapat digunakan 6-8 detik, sehingga penting untuk memiliki cadangan energi. ${ }^{1,6}$

Creatine $(\mathrm{Cr})$ merupakan jenis asam amino yang tersimpan sebagai sumber energi di dalam otot. Creatine mempunyai peranan penting dalam proses metabolisme energi secara anaerobik di dalam otot untuk menghasilkan ATP. ${ }^{1}$ Didalam otot, $\mathrm{Cr}$ yang sudah terfosforilasi yaitu phosphocreatine (PCr) dengan bantuan enzim creatine phosphokinase, $\mathrm{PCr}$ yang tersimpan didalam otot akan dipecah menjadi Pi (inorganik fosfat) dan Cr. Inorganik fosfat tersebut dapat mengikat adenosine diphosphate (ADP) melalui proses fosforilasi dan akan kembali membentuk molekul ATP (adenosine triphosphate). Melalui proses hidrolisis $\mathrm{PCr}$, energi dalam jumlah besar $(2.3 \mathrm{mmol}$ ATP $/ \mathrm{kg}$ berat basah otot per detiknya) dapat dihasilkan secara instan untuk memenuhi kebutuhan energi pada saat berolahraga dengan intensitas tinggi. Sistem ini tidak membutuhkan oksigen untuk menghasilkan ATP. Pada sistem ini ATP yang tersimpan di otot digunakan 2-3 detik pertama, kemudian menggunakan $\mathrm{PCr}$ untuk resintesa ATP sampai $\mathrm{PCr}$ di dalam otot habis yang bertahan sekitar kurang dari 10 detik. ${ }^{6,17,20}$

Sistem yang kedua adalah glikolisis anaerobik atau sistem asam laktat. Sumber energi terbaik selain PCr yaitu glikogen otot. Sebelum glikogen otot digunakan sebagai sumber energi, glikogen otot tersebut harus dipecah terlebih dahulu menjadi glukosa yang akan mengalami serangkaian reaksi untuk menghasilkan ATP proses tersebut disebut glikolisis. ${ }^{6}$ Prinsipnya adalah mengubah molekul glukosa menjadi dua molekul asam piruvat dimana dalam proses tersebut disertai pembentukan ATP. Molekul glukosa yang berasal dari darah akan menghasilkan dua mol ATP, sedangkan glukosa dari glikogen yaitu tiga mol ATP. ${ }^{18}$

Didalam tubuh jika ketersediaan oksigen terbatas atau pada saat pembentukan asam piruvat terjadi secara cepat seperti saat melakukan sprint, maka asam piruvat itu akan terkonversi menjadi asam laktat. ${ }^{18}$ Energi hanya dapat digunakan selama 2-3 menit selanjutnya akan mengalami kelelahan akibat timbunan asam laktat dalam darah dan otot. ${ }^{10}$ Diperlukan formula makanan yang aman untuk memperlambat terjadinya kelelahan otot yang akan menghasilkan performa yang lebih maksimal saat latihan maupun pertandingan. Selama pertandingan cadangan glikogen akan berkurang 50-60\% sehingga dapat dihubungkan dengan terjadinya kelelahan otot. Dianjurkan untuk makan utama 3 jam sebelum latihan ataupun pertandingan untuk memenuhi simpanan glikogen dan meningkatkan glikogen otot sekitar 11$15 \% .{ }^{21}$

Kandungan kalium pada buah pisang berfungsi dalam keseimbangan cairan, kekuatan dan kecepatan kontraksi otot, penyimpanan glikogen, serta menjadi transport glukosa kedalam sel. ${ }^{1,6}$ Mineral kalium bersama dengan natrium berperan dalam mekanisme kelelahan otot yaitu menjaga depolarisasi sarkolemal dan membrane $t$ tubular. Jika terjadi gangguan pada depolarisasi sarkolemal dan membrane $\mathrm{t}$ tubular maka akan menyebabkan gangguan regulasi ion $\mathrm{Ca}^{+}$di intrasel. Ion tersebut berperan dalam hal kontraksi otot yaitu dengan membuka jembatan silang miosin untuk mengikat aktin. Gerakan pada jembatan silang menyebabkan terjadinya kontraksi otot. Perubahan elektrolit dan gangguan keseimbangan cairan didalam tubuh akan mempengaruhi depolarisasi sarkolemal dan membrane $t$ tubular sehingga menimbulkan kelelahan otot karena kontraksi otot telah melemah. ${ }^{17,22-24}$

Pengaruh variabel perancu terhadap indeks kelelahan otot AF berdasarkan hasil recall zat gizi subjek menunjukkan bahwa tidak terdapat perbedaan yang bermakna $\boldsymbol{p}>0,05$ antara kecukupan energi, karbohidrat, asupan kalium, kalsium, dan natrium pada ketiga kelompok terhadap indeks AF. Hal ini dikarenakan rata-rata hasil analisis zat gizi dari asupan tersebut tergolong kurang. Glukosa darah akan disimpan sebagai glikogen otot dan hati jika asupan karbohidrat berlebih, namun dari hasil recall 24 jam menunjukkan bahwa kecukupan karbohidrat dalam kategori kurang sehingga glikogen yang tersimpan sedikit. Glikogen hati menurun ketika dalam keadaan puasa, karena ia memasok glukosa kealiran darah untuk jantung, otak, jaringan adiposa dan eritrosit. ${ }^{25}$ Pengisian glikogen otot meningkat dalam waktu 24-36 jam saat istirahat dengan konsumsi karbohidrat sebanyak 8-12 kg/BB/hari, selain itu simpanan glikogen otot akan meningkat jika menerapkan karbohidrat loading. ${ }^{6,26}$ Dari penjelasan tersebut, dapat disimpulkan bahwa variabel perancu dalam penelitian ini tidak berpengaruh terhadap indeks AF pada remaja di Sekolah Sepak Bola.

\section{SIMPULAN}

Berdasarkan penelitian yang telah dilakukan dapat disimpulkan bahwa terdapat perbedaan efektivitas antara buah pisang raja dan pisang ambon dalam mengatasi kelelahan otot anaerobik/Anaerobic Fatigue (AF). Perbedaan paling besar yaitu pada buah pisang raja. 


\section{SARAN}

Penelitian lebih lanjut dapat dilakukan dengan pemeriksaan laboratorium kadar asam laktat untuk mengetahui apakah pemberian pisang raja lebih efektif dalam menghambat akumulasi asam laktat dibandingkan dengan pisang ambon.

\section{UCAPAN TERIMAKASIH}

Puji syukur pada Allah SWT atas segala rahmat yang telah diberikan.Penulis juga mengucapkan terima kasih pada Laboratorium Ilmu Pangan Universitas Soegijapranata Semarang yang telah membantu dalam pelaksanaan penelitian ini. Tidak lupa pula penulis mengucapkan terima kasih untuk orangtua dan teman-teman atas segala dukungan, bantuan, dan doa yang telah diberikan.

\section{DAFTAR PUSTAKA}

1. Kementrian Kesehatan RI. Pedoman Gizi Olahraga Prestasi. Jakarta: Bakti Husada; 2014.

2. Chan HC, Fong DT, Lee JW, Yau QK, Yung PS, Chan K. Power and endurance in Hong Kong professional football players. Asia-Pacific J Sport Med Arthrosc Rehabil Technol. 2016;5:1-5.

3. Hasanah U. Perbedaan Nilai Kelelahan Anaerobik Atlet Sepak Bola yang diberikan Buah Semangka Merah dan Tidak Diberikan Buah Semangka Merah. J Nutr Coll. 2015;4:147-53.

4. Reza AB, Rastegar M. Correlation between Runningbased Anaerobic Sprint Test (RAST) field tests, Sargent jump and 300 yard shuttle run tests with laboratory anaerobic Wingate test in evaluation of indoor soccer player's anaerobiic readiness. 2012;3(1):377-84.

5. Kalva-filho CA, Loures JP, Papoti M. Comparison Of The Anaerobic Power Measured By The Rast Test At Different Footwear And Surfaces Conditions. Rev Bras Med Esporte. 2013;19(2):139-42.

6. Williams MH. Nutrition For Health, Fitness And Sport 8ed. New York,USA: McGraw-Hill; 2007. 81$137 \mathrm{p}$.

7. Chen HY, Cheng FC, Pan HC, Hsu JC, Wang MF. Magnesium enhances exercise performance via increasing glucose availability in the blood, muscle, and brain during exercise. PLoS One. 2014;9(1):e85486.

8. Jose J, Abia J, Coso J Del, Gonza C, Garde S, Pe B. Muscle Damage and Its Relationship with Muscle Fatigue During a Half-Iron Triathlon. PLoS One. 2012;7(8):1-7.

9. Endra Y. Analisis Proksimat Dan Komposisi Asam Amino Buah Pisang Batu (Musa balbisiana colla). Bogor: Institut Pertanian Bogor; 2006.

10. Kumairoh S. Pengaruh Pemberian Pisang (Musa paradisiaca) Terhadap Kelelahan Otot Anaerob pada Atlet Sepak Takraw. Semarang: Universitas Diponegoro; 2014.

11. Fridintya AG. Perbedaan Efektivitas Pemberian Jus Pisang Ambon dan Jus Pisang Raja Dalam Mengatasi
Kelelahan Otot pada Tikus Wistar. Universitas Diponegoro; 2011.

12. Ioannou I, Ghoul M. Prevention Of Enzymatic Browning In Fruit And Vegetables. Eur Sci J. 2013;9(30):310-41.

13. Miller KC. Plasma Potassium Concentration and Content Changes After Banana Ingestion in Exercised Men. 2012;47(6):648-54.

14. Michael J. Mc Kenna, Jens Bangsbo, and Jean-Marc Renaud M. Muscle $\mathrm{K}+, \mathrm{Na}+, \mathrm{Cl}$-disturbance and $\mathrm{Na}+\mathrm{K}+$ pump inactivation: implication for fatigue. $\mathrm{J}$ Appl Physiol 2008. 104: 288-295

15. Nieman DC, Gillitt ND, Henson DA, Sha W, Shanely RA, Knab AM, et al. Bananas as an Energy Source during Exercise: A Metabolomics Approach. 2012;7(5):4-10.

16. Kameswara I. Perbedaan Nilai $\mathrm{VO}_{2 \mathrm{MAX}}$ dan Jarak Tempuh Lari Antar Pemberian Susu Rendah Lemak dan Minuman Olahraga Komersial pada Atlet Sepak Bola. Nutr Coll. 2015;4:30-8.

17. Kusumastuti E. Pengaruh Pemberian Jus Jeruk Manis (Citrus Sinensis) Terhadap Indeks Kelelahan Otot Anaerob Pada Atlet Sepak Bola Di Gendut Dony Training Camp (GDTC). J Nutr Coll. 2016;5(Jilid 2):368-73.

18 Guyton AC, Hall JE. Textbook of Medical Physiology. $12^{\text {th }}$ rev. ed. Mississippi: Saunders Elsevier; 2010 June 15. P. 1029-31.

19 Freckmann G, Hagenlocher S, Baumstark A, Ph D, Jendrike N, Gillen RC, et al. Continuous Glucose Profiles in Healthy Subjects. 2007;1(5):695-703.

20 Westerblad H, Bruton JD, Katz A. Skeletal muscle : Energy metabolism, fiber types, fatigue and adaptability. Exp Cell Res. 2010;316(18):3093-9.

21. Williams C, Rollo I. Carbohydrate Nutrition and Team Sport Performance. Sport Med. 2015;45(1):13-22.

22. Whitney, E., Sharon RR. Understanding Nutrition. 11th Ed. USA : ThomsonWadsworth; 2007. p. 50845; 546-91.

23. Corwin, EJ. Patofisiologi: Buku Saku : alih bahasa Nike BS; editor Egy KY, Esty W, Devy Y, Pamilih EK. Edisi ke-3. Jakarta: EGC. 2009.p.444-448.

24. William CA, Sebastian R, editor. Human Muscle Fatigue.NY: Routledge. 2009.p.20-40.

25. Adeva-andany MM, González-lucán M, Donapetrygarcía C, Fernández-fernández C, Ameneirosrodríguez E. Glycogen metabolism in human. BBACLI. 2016;5:85-100.

26. Greene J, Louis J, Korostynska O, Mason A. Stateof-the-Art Methods for Skeletal Muscle Glycogen Analysis in Athletes - The Need for Novel NonInvasive Techniques. 2013;1-16. 